\title{
Chemical Properties of Charcoal Briquette with Composition Types of Gerunggang (Cratoxylon Arborescens) and Tumih (Combretocarpus Rotundatus) Wood from Tropical Peatlands
}

\author{
Alpian, Raynold Panjaitan, Yanciluk, Wahyu Supriyati, Emmy U. Antang and Sosilawaty
}

Faculty of Agriculture, University of Palangka Raya, Kampus UPR Tunjung Nyaho, Palangka Raya, 73111, Indonesia

Correspondence email : alpian@for.upr.ac.id

\begin{abstract}
Charcoal briquettes can be an alternative energy and can be produced from Gerunggang and Tumih types of wood. These two types of wood are commonly found in Kalampangan Village as pioneer plants on burned peatlands. The research objective was to determine the chemical properties of charcoal briquettes produced from biomass waste from land processing without burning with several compositions of Gerunggang wood and Tumih wood. The chemical properties of charcoal briquettes refer to the Indonesian National Standard (SNI 01-6235-2000) and Standard Permen ESDM No. 047 of 2006. The results showed that all composition treatments in the ash content test, fixed carbon content and calorific value met the standards, while the test for volatile content in all treatment compositions did not meet the Indonesian National Standard (SNI 016235-2000). The composition of the most potential chemical properties and following the two standards used is the composition of $100 \%$ Tumih with ash content of $7.67 \%$, volatile matter content of $27.23 \%$, fixed carbon of $55.00 \%$, and heating value of $5902.18 \mathrm{cal} / \mathrm{g}$.
\end{abstract}

Key words: charcoal briquette, chemical properties, biomass waste, Gerunggang, Tumih.

\section{INTRODUCTION}

The problem that occurs in Central Kalimantan during the long dry season is forest and land fires. Forests and peatlands are difficult problems to overcome in a fire because they are difficult to extinguish 2015 in various regions, including Kalampangan Village, Palangka Raya, Indonesia. After the fire, the land or forest will experience succession, the land will grow some pioneer plants such as Gerunggang and Tumih. Gerunggang (Cratoxylon arborescens) grows in swampy areas or the intermediate zone between swamps and dry land. Gerunggang is a pioneer plant that grows in tropical rain forests, especially on swampy soils, peat swamp lands and dry soils. Tumih (Combretocarpus rotundatus) is the most popular pioneer in degraded peatlands. Tumih can grow bigger, if conditions in the environment support it. Tumih wood has not been widely popularized. Tumih trees function more as a pioneer that is most resistant to inundation and can grow in nonperiodic inundated areas Gerunggang and Tumih overgrown peatlands such as in Kalampangan Village are widely used for farming and gardening. In clearing land, the community did not take full advantage of the Gerunggang and Tumih trees. Some people use large logs as woodworking material, but other parts that are not suitable for carpentry are only piled up after logging and let rot away. To increase the utilization of biomass by cultivating land without burning, one of which can be processed into charcoal briquette products that can be used as household fuel and has economic value if it has good quality standards for charcoal briquettes. Charcoal briquettes are alternative fuels made from the results of the burning process of materials that have a small size or diameter (twigs, powder, flakes, sebetan, coconut shell, candlenut shell and other biomass). The waste from charcoal in the form of small chunks of charcoal or powder can be converted into charcoal briquettes. Based on the above problems, research activities were carried out by utilizing Gerunggang and Tumih biomass waste to support government programs in Non-Burning Land Management by utilizing this waste as raw material for making charcoal briquettes with raw materials from unused tree organs such as leaves., twigs and branches of the type Gerunggang (Cratoxylon arborescens) and Tumih (Combretocarpus rotundatus) 
wood. The research objective was to determine the quality of charcoal briquettes' chemical properties produced from biomass waste in land cultivation without burning, which is divided into 5 compositions of Gerunggang and Tumih charcoal powder which refers to both standards. namely the standard standard Permen ESDM No. 047 of 2006 concerning guidelines for the manufacture and utilization of coal briquettes and coal-based solid fuels and charcoal briquettes standards, namely the Indonesian National Standard (SNI 01-6235-2000). Benefits Research can provide information to the community about the utilization of biomass that is not utilized in processing activities Unburned land becomes the raw material for making charcoal briquettes which have economic value as a renewable energy fuel for the community.

\section{METHODS}

\section{Material}

Equipment used in this research are machete, counting machine, sack, tarpaulin, iron mortar, charging stove, sieve (40 mesh and 60 mesh) plastic clips, analytical scales, glassware, oven, desiccator, $5 \mathrm{~cm}$ diameter mold, hydraulic press , UTM 5000 Cakra Mulya brand firmness tool, ash cup, ash kiln and calorimeter bomb. The materials used are Gerunggang and Tumih biomass, aquades as a solvent, tapioca flour as an adhesive and charcoal as fuel in the process of composing.

\section{Sampling and Drying}

Samples were obtained from community land in Kameloh Misik, RT/RW 07/04, Kalampangan Subdistrict, Sebangau Subdistrict, Palangka Raya, Indonesia (Figure 1). The parts taken include branches, twigs and leaves which are then counted using a counting machine. Drying the sample by air drying to reach the air dry air content.

\section{Formulation and Manufacture of Charcoal}

Powder Particles Weights and weights that have been weighed are put into the roasting furnace and then the charcoal is turned on under the stove until the temperature in the roasting furnace reaches $500^{\circ} \mathrm{C}$. After the temperature is reached, keep it for up to 1 hour and then cool down to 16 hours. Then the charcoal is removed from the container and then weighed to find out the charcoal rendering produced. The next process is that the charcoal is smoothed with a pound of iron clay and sifted using a 40 mesh retained 60 mesh. Enrichment of charcoal powder is separated according to the type and put in a plastic clip and labeled.

\section{Manufacture of Adhesives}

In the process of making adhesive material, tapioca is filtered using a 40 mesh pass filter held at 60 mesh and then dried in an oven at 60 ${ }^{\circ} \mathrm{C}$ for 6 hours. Then put in an airtight bottle. The amount of tapioca used is $10 \%$ of charcoal powder, the water used to make adhesive dough is 5: 1 of the amount of tapioca used. The flour is mixed with water and then stirred evenly and then heated to $70^{\circ} \mathrm{C}$ for 5 minutes until it becomes thick or gel.

\section{Charcoal Briquette Manufacturing and Printing}

Alpian (2002), the filtered charcoal powder is mixed with a gel-shaped adhesive material and then stirred evenly to not clump. The even dough is placed in a mold with a diameter of 5 $\mathrm{cm}$ and the desired height of briquettes $2 \mathrm{~cm}$ which is then printed using a hydraulic press. The sampling time of each test sample was performed for 30 minutes.

\section{Drying of Charcoal Briquettes}

Drying was done indoors at room temperature and weighed 1 x 24 hours until charcoal briquettes' constant weight was obtained.

\section{Charcoal Briquette Testing}

The charcoal briquettes produced were tested to include charcoal rendering, ash content (ASTM D 3174-04), volatile nutrient content (ASTM D 3175-02), carbon content (ASTM D 3172-89) and calorific value (ASTM D-2015).

\section{Data analysis}

Results were analyzed using descriptive analysis based on average values. A standard deviation analysis is also performed to see the distribution of data in the sample and how close the individual data points are to the average value of the sample. Results compared to ESDM Candy Standards Number 047 Year 2006 and SNI 01-6235-2000. 


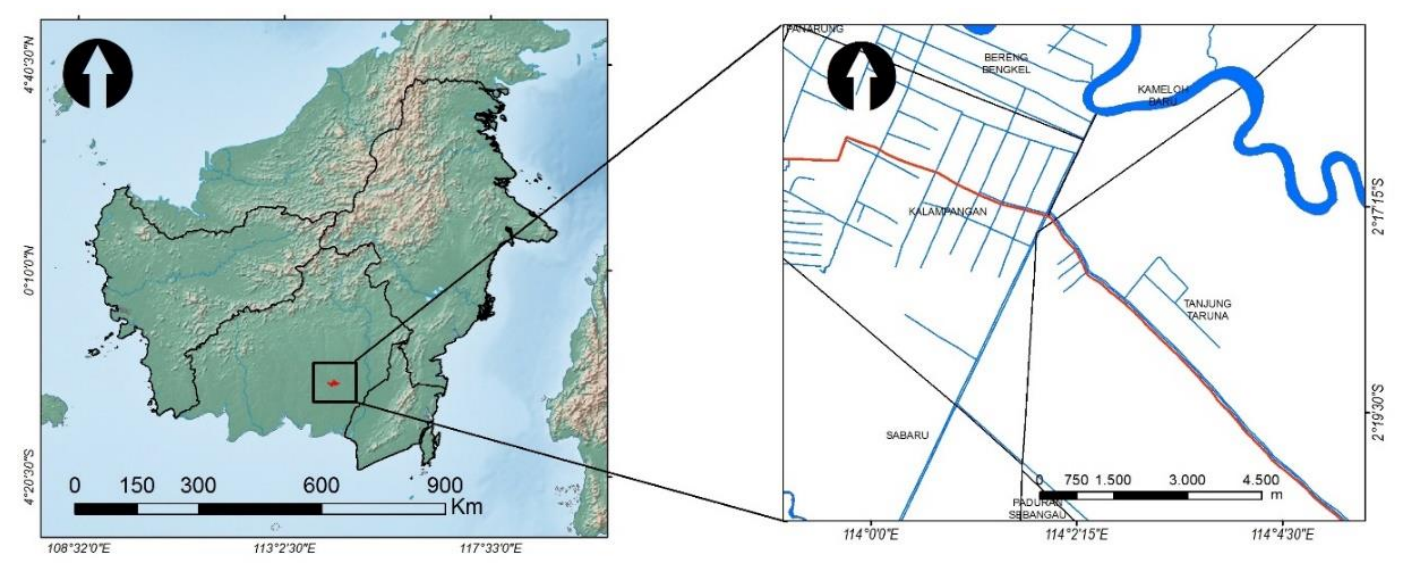

Figure 1. Research site (blue line is water body, red line is road)

\section{RESULTS AND DISCUSSION}

\section{Water content of raw materials and yield of charcoal}

The value of water content of raw materials and yield of charcoal is presented at Table 1 . Tumih wood show a higher content of water and rendement. Dumanauw (1990) states that the moisture content in wood varies greatly depending on the type of wood. The results showed that the higher water content of the raw material (Tumih) resulted in a higher yield of charcoal as well. This difference is caused by the specific gravity of the two raw materials used. High density of wood tends to produce high charcoal yield. Komaryati, et al. (2011) stated that wood with high specific gravity has a more compact and dense structure so that it is more resistant to being degraded by charcoal heat and causes higher yield of charcoal.

Table 1. The value of water content of raw materials and yield of charcoal

\begin{tabular}{lcc}
\hline \multicolumn{1}{c}{ Type } & Water Content (\%) & Rendement (\%) \\
\hline Gerunggang & 8.31 & 21.37 \\
Tumih & 8.51 & 25.00 \\
\hline
\end{tabular}

\section{Quality of Charcoal Briquettes}

Result of laboratory analysis for as content, Volatile matter content, fic carbon and alorific value of briquette of combine Tumih and Geronggang is presented at Table 2.

\section{Ash content}

Based on Table 2, the highest ash content values are in treatment $\mathrm{P} 1$ and $\mathrm{P} 5$, while the lowest is in $\mathrm{P} 2$ and $\mathrm{P} 4$. The value of ash content produced by all treatments still met the two standards used, namely SNI 01-6235-2000 and Permen ESDM N0. 047/2006. Specific gravity and mineral content affect the ash content of charcoal briquettes. The density of the two materials used is moderate so that it affects the increase in ash content. Low density of raw materials has a high mineral content. The difference in ash content is thought to be due to differences in the raw material's inorganic components. This is explained by Hendra and Winarni (2003) stating that the raw materials used have different chemical compositions and the number of minerals so that the resulting ash content is different. The biomass of Gerunggang and Tumih leaves in this study's composition is thought to increase the ash content in charcoal briquettes. This is according to the results of research by Komarayati et al. (2004) that charcoal from litter contains an ash content of $13.70 \%$ and Sasongko et al stated that jackfruit leaves contain an ash content of $14.3 \%$. Fengel and Wegener (1995) explain that the calcium (Ca) component has a total composition of $50 \%$ or more of the total element in wood ash, followed by $\mathrm{K}, \mathrm{Mg}, \mathrm{Mn}, \mathrm{Na}, \mathrm{P}, \mathrm{Cl}$ and other elements in small amounts. 
Table 2. Average Value of Charcoal Briquette Testing and Comparison with SNI 01-6235-2000 Standard and ESDM Regulation Number 047/2006

\begin{tabular}{|c|c|c|c|c|c|c|c|}
\hline \multirow{2}{*}{ Testing } & \multirow{2}{*}{$\begin{array}{l}\text { SNI 01- } \\
6235-2000\end{array}$} & \multirow{2}{*}{$\begin{array}{c}\text { ESDM } \\
\text { Regulation } \\
\text { Number } \\
047 / 2006 \\
\end{array}$} & \multicolumn{5}{|c|}{ Result } \\
\hline & & & $\mathrm{P} 1$ & $\mathrm{P} 2$ & P3 & P4 & P5 \\
\hline Ash content $(\%)$ & $\operatorname{Max} 8$ & $\leq 10$ & $7.67 \mathrm{ab}$ & $7.17 \mathrm{ab}$ & $7.50 \mathrm{ab}$ & $7.17 \mathrm{ab}$ & $7.67 \mathrm{ab}$ \\
\hline $\begin{array}{l}\text { Volatile matter } \\
\text { content }(\%)\end{array}$ & Max 15 & - & 27.23 & 27.37 & 27.10 & 27.95 & 27.42 \\
\hline Fixed Carbon (\%) & - & - & $55.00 \mathrm{ab}$ & $55.17 \mathrm{ab}$ & $55.00 \mathrm{ab}$ & $53.50 \mathrm{ab}$ & $53.50 \mathrm{ab}$ \\
\hline $\begin{array}{l}\text { Calorific value } \\
(\mathrm{kal} / \mathrm{g})\end{array}$ & Min 5000 & Min 4400 & $5902.18 \mathrm{ab}$ & $5601.91 \mathrm{ab}$ & $5880.19 \mathrm{ab}$ & $5923.99 \mathrm{ab}$ & $5786.98 \mathrm{bb}$ \\
\hline $\begin{array}{r}\text { Note }: \quad \mathrm{P} 1=100 \\
\mathrm{P} 2=25 \% \text { Tumih, } \\
\mathrm{P} 3=50 \% \text { Tumih, } \\
\mathrm{P} 4=75 \% \text { Tumih, } \\
\mathrm{P} 5=100 \% \text { Gerun } \\
\mathrm{a}=\text { Fulfil } \\
\mathrm{b}=\text { Fulfil }\end{array}$ & $\begin{array}{l}\text { Tumih, 0\% } \\
5 \% \text { Gerung } \\
0 \% \text { Gerung } \\
5 \% \text { Gerung } \\
\text { gang, } 0 \% \mathrm{~T} \\
\text { SNI 01-6235 } \\
\text { Regulation n }\end{array}$ & $\begin{array}{l}\text { Jerunggang } \\
\text { ang } \\
\text { ang } \\
\text { ang } \\
\text { mih } \\
2000 \\
\text { ESDM NO }\end{array}$ & $47 / 2006$ & & & & \\
\hline
\end{tabular}

\section{Volatile Substance Levels}

Based on the data in Table 2. that the highest volatile substance content was at $\mathrm{P} 4$ of $27.95 \%$ and the lowest was at $\mathrm{P} 3$ of $27.10 \%$. The value of volatile substances in all treatments did not meet SNI 01-6235-2000. This is due to the instability and imperfection of combustion in the coking process so that the vaporizing substance is not constant. This was also stated by Hendra (2008) that the high levels of volatile substances indicated that there were still non-carbon compounds attached to the surface of activated charcoal, especially hydrogen atoms which were firmly attached to carbon atoms on the surface of activated charcoal. This was also explained by Sadhukhan et al (2008) that in the pyrolysis process of biomass, volatile substances were formed. During the pyrolysis process, biomass loses weight slowly with increasing temperature. Biomass is turned into charcoal and primary volatile matter (G1) is formed. The charcoal refining stage occurs the formation of secondary volatile substances (G2). Lusyiani (2011) states that the high and low levels of flying substances are influenced by lignin and the carbonization process. The value of the very high volatile substance content greatly affects the value of the fixed carbon. Maryono et al (2013) stated that the content of high levels of volatile substances will cause a lot of smoke when the briquettes are ignited. The high smoke content is caused by the reaction between carbon monoxide (CO) and alcohol derivatives.

\section{Fixed Carbon Content}

Based on the data in Table 2, the fixed carbon content is found in $\mathrm{P} 2$ of $55.17 \%$ and the lowest in P4 and P5 of 53.50\%. The value of bonded carbon content produced by all treatments fulfilled the two standards used, namely SNI 01-6235-2000 and Permen ESDM NO. 047/2006 for not requiring (no value). The results showed that the ash content and volatile matter content affected the value of the fixed carbon. The low value of fixed carbon produced in this study was due to the value of water content and ash content and high levels of charcoal briquette volatile substances so that it affected the decreased content of fixed carbon. The value of low fixed carbon content is influenced by the pyrolysis process which is not optimal so that the volatile substance content is still high and the ash content is still high. The low carbon content indicates that the surface of the charcoal still contains noncarbon compounds (Pari, 1999). This was emphasized by Pari et al (1996) who also stated that the size of the carbon content was influenced by the amount of ash content and the level of flying substances that were still attached to the surface of the charcoal. Lusyiani (2011) states that the lower the flying substance and ash content, the higher the residual carbon value. Conversely, the higher the flying matter and ash content, the lower the residual carbon 
value. Triono (2006) stated that the high and low bonded carbon will greatly affect the heating value, where the high bonded carbon content will cause an increase in the carbon value so that the charcoal briquettes will be easily ignited.

\section{Calorific Value}

Based on the data in Table 2, the highest calorific value is in P4 of $5923.99 \mathrm{cal} / \mathrm{g}$ and the lowest is in P2 of $5601.91 \mathrm{cal} / \mathrm{g}$. The larger Tumih composition relatively produces a higher calorific value. The resulting calorific value meets the two standards used, namely SNI 01-6235-2000 and Permen ESDM N0. 047/2006. This was explained by Yokayoma et al. (2008) that trees contain the main components, namely hemicellulose, cellulose, and lignin, with different percentages. The use of biomass for energy is mainly biomass which contains a lot of lignin. This is confirmed by Bowyer et al. (2003). The formation of new cells in the cambium increases the diameter of the stem. The maturation of new xylem cells includes growth in cell diameter, cell length, cell wall thickening and cell lignification. This was also stated by Prawirohatmodjo (1999) that lignification is the final stage of cell development with the deposition of lignin in the cell wall. The calorific value is generally useful for efficiency (savings), which means that if the unit weight's heating value is high, it means that the amount of raw material used for the combustion process or heating process will be less. Kahariayadi et al (2015) stated that the calorific value greatly determines the quality of charcoal briquettes. The higher the calorific value of briquette charcoal, the better the charcoal quality of briquettes is produced. The higher the water content and the ash content of the briquette charcoal, the lower the calorific value of the charcoal briquettes.

\section{CONCLUSION}

The composition produces the most potential characteristics to meet the two standards used, namely SNI 01-6235-2000 and Permen ESDM N0. $047 / 2006$ is $100 \%$ Tumih composition with ash content of $7.67 \%$, volatile matter content of $27.23 \%$, fixed carbon 55.00 and a heating value of $5902.18 \mathrm{cal} / \mathrm{g}$.

\section{REFERENCES}

Alpian. 2002. Pengaruh Komposisi Serbuk Arang Kayu dan Limbah Industri Plywood dan Limbah Kayu HTI Terhadap Kualitas Briket Arang dengan Perekat Tepung Tapioka, Universitas Mulawarman, Samarinda.

ASTM Standards D . 2005. Standar Test Method for Gross Calorific Value of Coal and Coke by the Adibatic Bomb Calorimeter.In Annual Book of ASTM Standards, Section 5, Vol. 05.05. West Conhohocken, PA : American Society for Testing and Materials : 239-147.

Bowyer, J.L., Shmulsky, R. and Haygreen, J.G., 2003. Forest Product and Wood Science an Introduction. Iowa State Press Fourth Edition. Myers, R.H., Myers, S.L., dan Ye, K., 2002. Probablity and Statistics for Engineers \& Scientists 7'ed., Prentice Hall : 170-173.

BSN. 2000. SNI 01-6235-2000. Briket Arang Kayu. Badan Standarisasi Nasional. Jakarta.

Dumanauw, J, F. 1990. Mengenal Kayu. Yogyakarta : Kanisius.

Fengel, D. and G. Wegener. 1995. Wood : Chemistry. Ultrastructure, Reactions. Translation to Indonesia by Harjono Sastrohamidjojo. Gadjah Mada University Press. Yogyakarta : 254-257, 622.

Hendra, D. 2007. Pembuatan Briket Arang dari Campuran Kayu, Bambu, Sabut Kelapa dan Tempurung Kelapa sebagai Sumber Energi Alternatif. Jurnal Hasil Hutan. Bogor. Pusat Penelitian dan Pengembangan Keteknikan Kehutanan dan Pengolahan Hasil Hutan.

Hendra, D. 2008. Pengaruh Penggunaan Dua Distribusi Uap Air Panas dalam Pembuatan Arang Aktif dari Serbuk Gergaji Kayu Campuran. Badan Penelitian dan Pengembangan Kehutanan. Bogor. Jurnal Penelitian Hasil Hutan 26 (1) : 81-94. 
Hendra, D., I. Winarni. 2003. Sifat Fisis dan Kimia Briket Arang Campuran Limbah Kayu Gergajian dan Sebetan Kayu. Pusat Penelitian dan Pengembangan Teknologi Hasil Hutan. Bogor. Buletin Hasil Hutan 21 (3) ; 211-226.

Kahariayadi, A., D. Setyawati, Nurhaida, F. Diba, E. Roslinda. 2015. Kualitas Arang Briket Berdasarkan Persentase Arang Batang Kelapa Sawit (Elaeis guineensis Jacq) dan Arang Kayu Laban (Vitex pubescens Vahl). Jurnal Hutan Lestari Vol 3 (4) : 561-568.

Kementerian Energi dan Sumber Daya Mineral. Peraturan Menteri ESDM No. 47 Tahun 2006 tentang Pedoman Pembuatan dan Pemanfaatan Briket Batubara dan Bahan Bakar Padat Berbasis Batubara. Jakarta.

Komarayati, S., D. Setiawan dan Mahpudin. 2004. Beberapa Sifat dan Pemanfaatan Arang dari Serasah dan Kulit Kayu Pinus. Pusat Penelitian dan Pengembangan Teknologi Hasil Hutan. Bogor. Jurnal Penelitian Hasil Hutan 22 (1) : 17-22.

Komaryati, S., Gusmailina, G. Pari. 2011. Produksi Cuka Kayu Hasil Modifikasi Tungku Arang Terpadu. Jurnal Penelitian Hasil Hutan Vol 29 (3) : 234247.

Lusyiani. 2011. Analisis Sifat Fisik dan Kimia Briket Arang dari Campuran Kayu Galam (Melaleuca leucadendron Linn) dan Tempurung Kemiri (Aleurites moluceana Wild). Jurnal Hutan Tropis Vol 12 (32).

Maryono, Sudding dan Rahmawati. 2013. Pembuatan dan Analisi Mutu Briket Arang Tempurung Kelapa di Tinjau dari Kadar Kanji. Makassar. Jurusan Kimia FMIPA Universitas Negeri Makassar.

Pari, G. 1999. Karakteristik Arang Aktif dari Serbuk Gergajian Sengon dengan Bahan Pengaktif NH4CO3. Pusat Penelitian dan Pengembangan Hasil Hutan dan Sosial Ekonomi Kehutanan. Buletin Penelitian Hasil Hutan 17 (2) : 89-100.
Pari, G., D. Setiawan dan Mahpudin. 1996. Hasil Destalasi Kering 10 Jenis Kayu dari Nusa Tenggara Barat. Buletin Penelitian Hasil Hutan. Pusat Penelitian dan Pengembangan Hasil Hutan dan Sosial Ekonomi Kehutanan. Bogor. Buletin Penelitian Hasil Hutan 14 (9) : 382-387.

Prawirohatmodjo, S. 1999. Struktur dan SifatSifat Kayu. Teknologi Hasil Hutan. Fakultas Kehutanan. Universitas Gadjah Mada. Yogyakarta.

Republik Indonesia. Undang Undang No. 32 Tahun 2009 Tentang Perlindungan dan Pengelolaan Lingkungan Hidup. Jakarta

Rindayatno, M. K. Sari, S. Wagiman. 2017. Kualitas Briket Arang Berdasarkan Komposisi Campuran Arang dari Kayu Meranti Merah (Shorea sp.) dan Tempurung Kelapa (Cocos nucifera L.). Prosiding Seminar Nasional Ke-1. Balai Riset dan Standarisasi Industri. Samarinda.

Sadhukhan, A. K., P. Gupta, T. Goyal dan R. K. Saha. 2008. Modelling of Pyrolisys of Coal-Biomass Blends usin Thermogravimetric Analysis. Bioresource Technology. 99 (2008) : 8022-8026.

Sasongko, W.T., W.T., L. M. Yusiati, Z. Bachruddin dan Mugiono. 2010. Optimalisasi Pengikatan Tanin Daun Nangka Dengan Protein Bovine Serum Albumin. Buletin Peternakan 34 (3) : 154-158.

Triono. 2006. Karakteristik Briket Arang dari Campuran Serbuk Gergajian Kayu Afrika (Maesopsis emini Engl.) dan Sengon (Paraserianthes falcataria L.). Skripsi. Bogor. Departemen Hasil hutan. Fakultas Pertanian. Institut Pertanian Bogor.

Yokayama, S., Y. Matsumura, S. Ando, K. Shakanishi, H. Sano, T. Minowa, H. Yamamoto, dan T. Yoshioka. 2008. The Asia Biomass Handbook "A Guide for Biomass Production and Utilization". The Jepan Institute of Energy. 